\title{
A rare case of food poisoning by Kudoa hexapunctata
}

\author{
Yoshihito Takashima, Tsuyoshi Suda (1) , Naoki Oishi, Eiki Matsushita
}

Gastroenterology, Kanazawa Municipal Hospital, Kanazawa, Japan

\section{Correspondence to \\ Dr Tsuyoshi Suda:}

t.suda1112@gmail.com

Accepted 2 September 2021

\section{DESCRIPTION}

A 32-year-old man was admitted to our hospital at midnight with vomiting and diarrhoea after eating sashimi for dinner. On physical examination, his abdomen was flat and tender with weak peristalsis, but no rebound tenderness or abdominal rigidity. $\mathrm{He}$ was febrile with a temperature of $38.2^{\circ} \mathrm{C}$. Blood tests revealed an elevated white cell count $\left(16 \times 10^{9} / \mathrm{L}\right)$, with all other parameters, including C-reactive protein, within the normal range. The fever, vomiting and diarrhoea resolved within 24 hours.

Spores of Kudoa species were detected in a stool culture.

Kudoa's spores are surrounded by three or more shell valves that are symmetrically radial, each having one polar capsule. The suture line where the

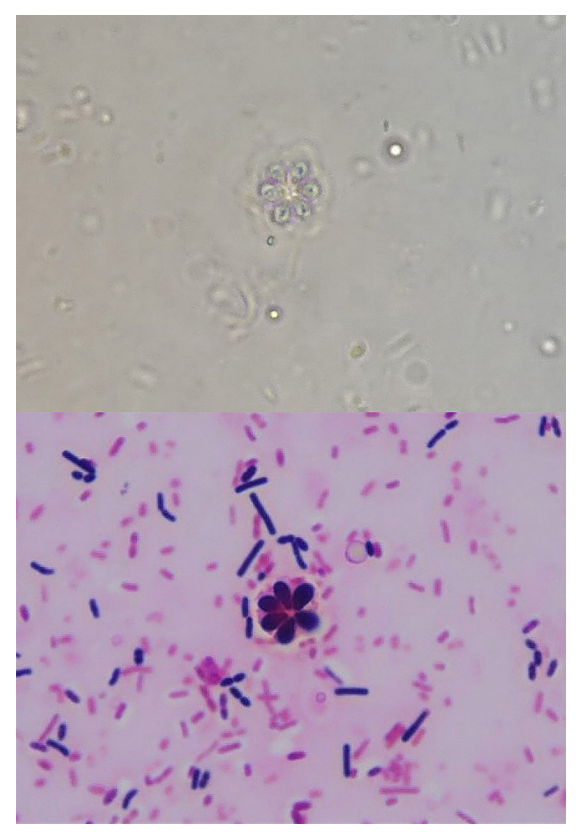

Figure 1 A spore surrounded by three or more shell valves, symmetrically radial, with a polar capsule each, detected in a stool culture. shells meet is often indistinct (figure 1). PCR testing confirmed the presence of Kudoa hexapunctata, a mucus sporozoite that is found in bluefin tuna (especially young bigeye tuna); it was taxonomically separated from Kudoa neothunni (which is found in yellowfin tuna) and other species since tuna is their primary host. ${ }^{1} \mathrm{Kudoa}$ food poisoning is associated with the consumption of raw fresh fish, such as sashimi. It manifests as diarrhoea and vomiting within 12 hours of eating the contaminated food and usually resolves within 24 hours. ${ }^{2}$

\section{Learning points}

Kudoa food poisoning is associated with raw fresh fish consumption.

- It manifests as diarrhoea and vomiting within 12 hours of eating the contaminated food.

- It usually resolves within 24 hours.

Acknowledgements We are grateful to Mrs Yuka Umeda and Mrs Riho Matsuoka (Kanazawa Municipal Hospital,Clinical Laboratory Center) for helping with a bacteriological examination.

Contributors YT cared for the patient, edited the manuscript and prepared the figure. TS cared for the patient, conducted the literature search and edited the manuscript. NO and EM edited the manuscript and gave the expert opinion of gastroenterology.

Funding The authors have not declared a specific grant for this research from any funding agency in the public, commercial or not-for-profit sectors.

Competing interests None declared.

Patient consent for publication Obtained.

Provenance and peer review Not commissioned; externally peer reviewed.

\section{ORCID iD}

Tsuyoshi Suda http://orcid.org/0000-0001-9608-0444

\section{REFERENCES}

1 Arai S, Yoshinari T, Terajima J, et al. Detection of Kudoa hexapunctata and Kudoa neothunni from retail raw tuna in Japan using a novel duplex polymerase chain reaction. Parasitol Int 2020;75:102048.

2 Sugita-konishi Y, Sato H, Ohnishi T. Novel foodborne disease associated with consumption of raw fish, olive flounder (Paralichthys olivaceus). Food Saf 2014;2:141-50. 
Copyright 2021 BMJ Publishing Group. All rights reserved. For permission to reuse any of this content visit https://www.bmj.com/company/products-services/rights-and-licensing/permissions/

BMJ Case Report Fellows may re-use this article for personal use and teaching without any further permission.

Become a Fellow of BMJ Case Reports today and you can:

- Submit as many cases as you like

- Enjoy fast sympathetic peer review and rapid publication of accepted articles

Access all the published articles

Re-use any of the published material for personal use and teaching without further permission

Customer Service

If you have any further queries about your subscription, please contact our customer services team on +44 (0) 2071111105 or via email at support@bmj.com.

Visit casereports.bmj.com for more articles like this and to become a Fellow 